\title{
ASOSIASI ANTARA SITUASI EMOSI, KEPATUHAN PADA ORAL ANTI DIABETES, DAN HEMOGLOBIN TERGLIKASI PADA PENYANDANG DIABETES MELLITUS TIPE 2
}

(The Association Of Emotional Situation, Adherence To Oral Anti-Diabetes, And Glycated Hemoglobin In Diabetes Type 2 Patients)

Inge Wattimena' ${ }^{1}$, Galuh Nawang Prawesti ${ }^{2}$

\begin{abstract}
The problem of diabetes, which is predicted to increase in number of people suffering from diabetes in the upcoming years, needs to be examined from a bio-psycho-social perspective. This chronic illness which is difficult to be cured, affects the emotional situation and also the adherence to oral anti-diabetes $(O A D)$. The objective of this study is to examine the relationship between bio-physiology of the body (measured by the glycated hemoglobin level of HbAlc) and the emotional situation and adherence to OAD. Observational research with a cross-sectional approach was carried out on 76 type 2 diabetics who were treated at the Gotong Royong Hospital (RSGR) Surabaya. Research data was taken through a valid and reliable questionnaire about emotional situation and adherence to OAD. The glycated hemoglobine was measured in the RSGR laboratory. Inferential analysis was tested using Spearman correlation test. The results showed a significant negative correlation power between the emotional situation and the level of HbAlc $(r=-0.256, p=0.026)$, as well as between the level of adherence to OAD and the level of HbAlc $(r=-0.402, p=0.000)$. Those outcomes indicated that the more positive the emotional situation, as well as the higher the level of adherence to $O A D$, the better health outcome of the diabetic patient. These results enrich the educational material in health promotion. Enhancing the positive emotional situation and the level of adherence to $O A D$ will decrease the morbidity and mortality rates due to diabetes, and optimize the welfare of the patient.
\end{abstract}

Keywords: Diabetes, Emotion, Adherence, Glycated Hemoglobine

\begin{abstract}
ABSTRAK
Masalah diabetes, yang diramalkan semakin meningkat jumlah penyandangnya pada tahuntahun yang akan datang, perlu diteliti dari perspektif bio-psiko-sosial. Penyakit kronis yang sulit
\end{abstract}


disembuhkan ini memberi dampak pada situasi emosi dan juga pada tingkat kepatuhan terhadap oral anti diabetes (OAD). Tujuan penelitian adalah menganalisis hubungan antara bio-fisiologi tubuh (diukur dengan kadar hemoglobin terglikasi HbA1c) dengan situasi emosi dan kepatuhan terhadap OAD. Penelitian observational dengan pendekatan cross-sectional dilakukan pada 76 penyandang diabetes tipe 2 yang dirawat jalan di Rumah Sakit Gotong Royong (RSGR) Surabaya. Data penelitian diambil melalui item-item yang valid dan reliabel dari kuesioner situasi emosi dan tingkat kepatuhan. Kadar HbA1c diperiksa di laboratorium RSGR. Analisis inferensial dilakukan dengan uji korelasi Spearman. Hasilnya menunjukkan adanya korelasi negatif dan bermakna antar situasi emosi dan kadar HbA1c $(r=-0,256 ; p=0,026)$, demikian pula antara tingkat kepatuhan terhadap OAD dan kadar HbA1c $(r=-0,402 ; p=0,000)$. Hasilhasil ini menggambarkan bahwa semakin positif situasi emosi maupun semakin tinggi tingkat kepatuhan terhadap $\mathrm{OAD}$, semakin baik keadaan penyakit diabetes penyandangnya. Hasil penelitian ini berkontribusi sebagai bahan edukasi sewaktu melakukan promosi kesehatan. Dengan semakin positifnya situasi emosi dan semakin meningkatnya tingkat kepatuhan terhadap $\mathrm{OAD}$, diharapkan morbiditas dan mortalitas akibat diabetes semakin menurun, dan kesejahteraan penyandangnya semakin optimal.

\section{Kata Kunci: Diabetes, Emosi, Kepatuhan, Hemoglobin Terglikasi}

\footnotetext{
1)\#Departemen Ilmu Kesehatan Masyarakat, Fakultas Kedokteran Universitas Katolik Widya Mandala Surabaya, J1 Raya Kalisari Selatan No 1 Tower A Lt 6, Pakuwon City Surabaya. No telp: 081938346880, email korespondensi: ingewben@yahoo.com

${ }^{2)}$ Departemen Farmasi Klinik dan Komunitas, Fakultas Farmasi Universitas Katolik Widya Mandala Surabaya, J1 Raya Kalisari Selatan No 1 Tower B Lt 4, Pakuwon City Surabaya
}

\section{INTRODUCTION}

The world faces the problem of diabetes mellitus (DM) as a health threat that is increasingly widespread and not easily to overcome. $\mathrm{WHO}^{1}$ stated that Indonesia ranks fourth in number for people with diabetes (after America, China and India), and estimated an escalation of people with diabetes in Indonesia from 8.4 million in 2000 to around 21.3 million in 2030. Badan Penelitian dan Pengembangan
Kesehatan Indonesia ${ }^{2}$ assumed that 13.7 million Indonesian people with diabetes will increase to 20.1 million by 2030 , with a prevalence of $14.7 \%$ in urban and $7.2 \%$ in rural areas.

Diabetes disturbs the physical as well as the psychological and social life. It can be assumed that the greater the diabetic problem, the greater the burden of the person, family, and the environment is. 
The World Health Organization ${ }^{1}$ defines a diabetic person as an individual with fasting blood sugar more than 126 $\mathrm{mg} / \mathrm{dl}$, or is in medication because of an increase in blood sugar. This WHO report explains that people with diabetes have twice the chance to suffer from complications such as stroke, kidney failure (especially in developing countries), amputation of the lower limbs (which is 10 times more in diabetic person rather than non-diabetic), deterioration of vision until the occurrence of blindness, and is easily infected by tuberculosis germs.

Complications in diabetes is the third highest cause of death in Indonesia ${ }^{3}$. The prevalence of diabetes in East Java is 2.5 percent and is among the top ten among provinces in Indonesia. Diabetes is a chronic disease and difficult to cure. Selfcare plays an important role in controlling this complex disease. Briggs ${ }^{4}$ explained that it needed an effective self-management in bio-psycho-social skills, a dynamic process in which sufferers actively regulate themselves to face this chronic disease.

Most people with type 2 diabetes fails to control blood sugar levels only on a diet and exercise. Treatment with oral antidiabetes (OAD) as monotherapy, or combined with insulin injection is important. Adherence to treatment still remains low even though education is carried out intensively ${ }^{5}$.
Improvement of diabetes can be monitored by the level of glycated hemoglobin $(\mathrm{HbA1c})$ which normally is less than $7 \%$. The expected condition is only reached by around 50\% of people with diabetes, which may be caused by nonadherence to therapy ${ }^{6}$.

Diabetes control needs to be reviewed from a biological and psychological perspective. Adherence to medication is a picture of psychological strength, in which the quality can be related to psychological strength of emotions. Emotion in human function as energizer to provide excitement in life; as messenger that is reflected on physical behavior or body reaction; as reinforcer of information; and as life balancer ${ }^{8}$. Mind, body, and health are interacting life factors in unity ${ }^{9}$.

Based on those references, we questioned this in our research: "how are the associations between emotional situation, level of adherence to oral antidiabetes, and level of $\mathrm{HbA} 1 \mathrm{c}$ in diabetes type 2 patients?" The objective of this study is to identify the asssociations between emotional situation, level of adherence to oral anti-diabetes, and level of HbA1c in diabetes type 2 patients."

\section{METHODS}

A quantitative observational approach with a cross-sectional study design was carried out on 71 type $2 \mathrm{DM}$ outpatients of the 
Gotong Royong Hospital in Surabaya that fulfilled the inclusion and exclusion criteria. The variables studied are the dependent variable $\mathrm{HbA} 1 \mathrm{c}$ level, and the independent variables are emotional situation and level of adherence to OAD. Level of $\mathrm{HbA1c}$ were measured in the hospital laboratory. A good diabetic level is $\leq 7 \%$.

The instrument of emotional situation consists of 17 statements (with 5 choices of answers between strongly disagree and strongly agree) which are valid and reliable. The factors traced are emotions in facing reality, self-regulation, monitoring disease, reducing risk, and carrying out activities. The instrument level of adherence (MMAS-8 instrument) consists of 8 valid and reliable dicotomic questions, tracing feeling and behavior in taking OAD. The descriptive research data were inferentially analysed using Spearman correlation test, and also transformed into cathegorical data.

\section{RESULTS}

Subject demographics showed that most subjects were above the age of 60 years, had high school education, and suffered diabetes below 5 years. The categories of most subjects were poor level of $\mathrm{HbA1c}$, moderate level of adherence, and positive emotional situation.

Inferential analysis by Spearman test showed: a) a negative significant correlation power between emotional situation and level of $\mathrm{HbA1c}(r=-0.256, \mathrm{p}$ $=0.026)$; b) a negative significant correlation power between level of adherence to OAD and level of HbA1c $(r=$

Tabel 1: Category and distribution of level of HbA1c, emotional situation, and level of adherence

\begin{tabular}{|l|l|c|c|c|c|}
\hline & Category - \% & Minimal & Maximal & Mean & Standard Deviation \\
\hline Level of HbA1c & $\begin{array}{l}\text { bad }(>7 \%) 76,5 \% \\
\text { good }(\leq 7 \%) 23,5 \%\end{array}$ & 5,60 & 15,00 & 8,72 & 2,27 \\
\hline $\begin{array}{l}\text { Level of } \\
\text { Adherence }\end{array}$ & $\begin{array}{l}\text { high 8,2\% } \\
\text { moderate 50,6\% } \\
\text { low 41,2\% }\end{array}$ & 2 & 8 & 5,63 & 1,5 \\
\hline $\begin{array}{l}\text { Emotional } \\
\text { Situation }\end{array}$ & $\begin{array}{l}\text { positive 57,9\% } \\
\text { negative 42,1\% }\end{array}$ & 52 & 71 & 60,99 & 4,39 \\
\hline
\end{tabular}

Tabel 2: Correlation between variabels

\begin{tabular}{|l|c|c|}
\hline Variable correlation & Correlation strength (r) & Significancy (p) \\
\hline ES-LH & $-0,256$ & 0,026 \\
\hline LA-LH & $-0,402$ & 0,000 \\
\hline ES-LA & 0,115 & 0,322 \\
\hline
\end{tabular}

LH= Level of HbA1c ES= Emotional Situation $\quad \mathrm{LA}=$ Level of Adherence 
$-0.402, \mathrm{p}=0.000)$; and c) no significant correlation power between emotional situation and level of adherence to OAD (r $=0.115, \mathrm{p}=0.322)$. The normality test of the dependent variable showed an abnormal distribution $(\mathrm{p}=0.000)$ despite data transformation $(\mathrm{p}=0.040)$. Thus bivariate and multivariate regression tests were not performed. It was shown that the research hypothesis which stated a significant association between emotional situation and level of $\mathrm{HbAlc}$, as well between level of adherence to OAD and level of HbA1c, are true.

\section{DISCUSSION}

\section{Subject Characteristics}

The average age of subjects is around 60 years, mostly have senior high school education, and suffer diabetes between 3 months and 5 years. Infodatin ${ }^{10}$ reports that the proportion of diabetes increases with age, and tends to be higher in groups with lower education. It is reported that in America ${ }^{11}$ the largest group of people with diabetes is between ages 45 and 64 years, and tends to be higher in the lower educated group (10.4 per 1000) compared to the higher educated group (5.3 per 1000).

Most of the subjects in this study have diabetes for less than 5 years. Charles $^{12}$ showed that proportion of poor glycemic control increases with duration of disease. The longer it suffers, the more progressive the disruption of insulin secretion occurs due to failure of pancreatic $\beta$ cells and increase in insulin resistance to control blood sugar levels, which ultimately further decrease insulin secretion ${ }^{13}$.

\section{Level of HbA1c}

In this study, most subjects are in the poor category level of HbAlc. This means that most subjects have high glucose levels that are bound by red blood cell hemoglobin at least for the last 8-12 weeks before the laboratory examination. This situation indicates the severity of the diabetic situation. The subjects are more likely to experience a negative impact due to the progression of the disease, such as the occurrence of micro and macroangiopathy complications with all its consequences ${ }^{14}$.

The level of HbA1c, which describes the situation of blood sugar control in a person, depends on the condition of people self-management. Those with unfavorable life situations may have poor blood sugar control, which generally describes their state of diabetes self-care. The target of decreasing HbAlc is generally only achieved by less than $50 \%$ of patients ${ }^{15}$.

\section{Emotional Situation}


Most of the emotional situation of research subjects are in the positive category. This favorable condition is a supporting factor in controling the disease. Factors explored are facing reality (to be patient and calm in dealing with diabetes), in self-regulation (to be able to follow medical directions and adherence to OAD), in monitoring (regularly conducting blood checks), in reducing risk factors (diligently doing exercises, paying attention to balanced intake), and in activities (socializing).

Positive emotions provide reinforcement and empowerment in selfmanagement in controlling their chronic diseases through attitude, belief, thought, awareness, acceptance, coping, and action skills. With these diverse positive skills, people with diabetes manage a well balanced intake, monitor their blood sugar, regulate body weight, follow a regular treatment regimen, and do physical exercises ${ }^{9}$.

In this study, $42.1 \%$ of the subjects are in a negative emotional situation. They were assessed in the face of reality (sadness and hate facing diabetes), in self-regulation (tired in following medical direction and difficult to adhere to OAD), in monitoring (tired of regularly carrying out blood checks and worrying about routine checks), in reducing risk (being heavy and lazy to exercise and pay attention to balanced intake), and in activities (avoiding social life).

The possibility of depression occurrence in people with diabetes is two times greater than in those without ${ }^{15}$. Symptoms of depression, which is often accompanied by feelings of anxiety and anger, are not easily detected by health-care workers due to the absence of treatment to restore the condition. This negative situation, which is more prevalent among women with diabetes than men, has an impact on poor self-management in the face of the disease. Concern for sickness and adherence to medicine decreases, blood sugar control is ignored, which ends in deteriorating quality of life. One form of negative emotional situation is fatigue and burnout in caring for oneself, especially if there are complications ${ }^{5}$. Ignorance of selfcontrol, uncontrolled eating, difficulty sleeping, pessimism, and loss of concentration are prominent.

To be in a positive emotional situation with a chronic disease condition such as diabetes, an emotional strength is needed, which among others is formed by intelligence. It is the person who manages emotional intelligence (emotional quotient). He needs to be aware in observing and recognizing the feelings he has; intelligent in positive managing unpleasant emotions to become a more acceptable and pleasant emotional 
situation; and motivating oneself to intelligently be able to support the achievement of his personal goals. Overall, the bio-psycho-social situation and the goals to be achieved intelligently are balanced for their welfare ${ }^{8}$.

\section{Level of Adherence to OAD}

Adherence to OAD factors studied were the routinity in taking and stopping medication, obeying rules, and remembering of taking medication. In this study about half of the subjects $(50.6 \%)$ were in the moderate level category, and $8.2 \%$ in the high level. Both of these categories describe the subjects good level of adherence to OAD.

Research by Rasdianah $^{7}$ in Yogyakarta, who also used the MMAS-8 instrument, showed that level of adherence to OAD of people with type $2 \mathrm{DM}$ was at the poor level category. This result is more or less the same as the findings in our study, where subjects in the poor level category is quite large $(41,2 \%)$.

Adherence to medication is an attitude resulting from self-motivation, an autonomy motivation that develops the skills and capacity to regulate the behaviors needed to function effectively. This situation applies if someone feels that the behavior has meaning to the person. In the case of diabetes, this motivation occurs when he feels initiated and gives a specific value to the behavior of the results of his self-management ${ }^{16}$.

The World Health Organization states that the average adherence to medicine in people with chronic disease is only $50 \%$ in developing countries. This is recognized to be a significant public health problem, because non-adherence to medicine will result in poor health outcome and increases health care costs ${ }^{17}$. A key factor contributing to the very high morbidity and mortality rates in people with type 2 diabetes is chronic poor metabolic control, especially poor glycemic control. Although many options are available now for the treatment of type $2 \mathrm{DM}$, including some drugs with new pharmacological classes recommended by the American Diabetes Assocation/European Association for the Study of Diabetes (ADA / EASD) and the American Association of Clinical Endocrinologists (AACE), 50\% type $2 \mathrm{DM}$ sufferers fail to achieve adequate glycemic control (measured by glycated hemoglobin $\mathrm{HbAlc})^{5}$.

\section{Emotional Situation and Level of HbA1c}

Results of this study showed a significant negative correlation power between emotional situation and level of HbA1c, which means that the more positive the emotional situation, the lower the level of $\mathrm{HbA1c}$, or the better the diabetes 
condition. Such correlations are also found in Strandberg et al research ${ }^{18}$.

What is the correlation if the emotional situation is negative? This situation was examined by Perrin et al ${ }^{19}$ with respect to the results of less than optimal result in diabetic treatment. Data was searched in 7 databases that produced 55 studies with a total of 36,998 cases of type II DM. The results showed that the prevalence of patients who experienced distress is $36 \%$. This situation is likely to be the cause of poor outcomes in treatment for diabetic patients.

Poor outcomes in diabetic patients was studied by Aikens ${ }^{20}$. He studied 253 patients with type 2 DM who had depressive symptoms (DS) and diabetesrelated distress (DRD). DS and DRD are predictors of medication adherence and self-care behavior for diet, body exercise, and checking blood sugar. The results of his research showed that DS had a significant effect on diet control, body exercise, and blood sugar examination. In other words, DS has an effect on future life-styleoriented self-management behaviors. DRD predicts blood sugar control and treatment adherence in the future.

\section{Level of Adherence to OAD and Level of HbA1c}

Result showed a significant negative correlation power between level of adherence to OAD and level to $\mathrm{HbA1c}$, which means that the higher the level of adherence, the lower the level of $\mathrm{HbA1c}$, or the better the diabetic condition is. These results are supported by the research of Wong ${ }^{21}$, Raum ${ }^{22}$, and Krapek ${ }^{23}$ which stated that the results of measurements of adherence (using MMAS-8 instrument) correlated significantly with better glycemic control.

Recommended level of blood sugar and good level of HbA1c $(\leq 7 \%)$ are only achieved by less than $50 \%$ of people with diabetes $^{6-5}$. This result is more or less the same as the findings in our study where $76.5 \%$ were in the poor level category of HbA1c. This alarming situation can lead to more complications.

Long-term control of blood sugar level that are routinely measured by $\mathrm{HbA} 1 \mathrm{c}$ is one of the most important targets in the management of people with type 2 diabetes. Good blood sugar control is obtained when the person follows the diet, uses the drug appropriately, and do exercises. The consequence of non-adherence in medicine can result in sub-optimal blood glucose control $^{3}$. Some other factors that affect glycemic control are feelings of treatment (benefit, cost, complexity, comfort, and trust), hypoglycemic side-effect, and trust in the physician 5 .

Level of Adherence to OAD and Emotional Situation 
The inferential test showed no significant correlation power between those two variables. This condition was not shown in Berenguera's study ${ }^{24}$. Through qualitative research he explained that when diagnosed as a diabetic, a person feels and thinks that his future is threatened. Related emotions are fear, anxiety, denial, and sadness. Various ways of adaptation are seen, and the approaches that are needed are also diverse, especially in the aspects of diet regulation, physical exercise, and treatment. Those with type 2 diabetes and poor control experienced difficulties in balansing the needs and necessities of diabetes management and control because it interferes with the continuity of his daily life. This qualitative research illustrates a relationship between emotions and selfmanagement, among others in adherence to medicine, which affects the outcome of the disease.

\section{Level of Adherence to OAD, Emotional Situation, and Level of HbA1c}

In this study, the dependent variable data of $\mathrm{HbA1c}$ has no normal distribution. Due to this condition, a mutivariat analysis of the three variables could not be done. However, each of the two independent variable has a significant negative correlation power with levels of HbA1c. Or it can be said that the higher the level of adherence to $\mathrm{OAD}$ and the more positive the emotional situation, the lower the
HbA1c level, which means the better the diabetic condition. There is no significant correlation power between emotional situation and level of adherence to OAD.

Emotional situation and adherence to medicine are self-care systems that play a role in health. Diabetes is a primarily selfmanageable condition, according to Isaac et $\mathrm{al}^{25}$. Their study was conducted on 143 elderly people with type $2 \mathrm{DM}$ who were outpatients in a Malaysian hospital. Observed were personal activities to control food intake, body activity, blood sugar level monitoring, and adherence to medication. The mean age of the subjects were 68 years, and the mean $\mathrm{HbA1c}$ was 8.4. The results showed that factors significantly affected diabetes self-care were ethnicity, family support, sufficient knowledge of diabetes and diabetic microvascular complications. Selfmanagement has an important role in controlling symptoms, adhering to treatment, minimizing physical and psychological consequences, and changing life-style that is recommended in carrying out this difficult to cure chronic illness.

Self-management requires emotional intelligence in self-regulation to control blood sugar. Levels of HbA1c were significantly associated with the intensity of affection and emotional intelligence, as well as diabetes self-care ${ }^{26}$. 
Emotions and obedience are psychological elements of one's cognition and affection, which then manifest in attitude and behavior, and might influence body's bio-physiology. Straub ${ }^{9}$ argues that "the mind and body are inextricable intertwined ... behaviors, thoughts, and feelings are affected by the functioning of the body."

This study revealed that most subjects were in positive emotional situations and moderate levels of adherence to OAD. This good condition reinforced self-management in dealing with this chronic disease. Positive condition results in good self-control and great optimism, all of which causes optimal mental and physical well-being'. This statement is not reflected in our research where most subjects have positive emotional situation and moderate level of adherence to OAD, but poor level of HbAlc. This fact needs to be further investigated.

\section{CONCLUSION}

Emotional situation and adherence to $\mathrm{OAD}$ have a significant negative correlation power with level of HbA1c. This means that the more positive the emotional situation as well as the higher the level of adherence to OAD, the lower the level of $\mathrm{HbA} 1 \mathrm{c}$ or the better the state of diabetes is. Adherence to OAD in this study is a psychological element that is not correlated with emotional situations. Overall the level of HbA1c was seen to be mostly poor even though the emotional situation and level of adherence to OAD were good. There are other factors, (eq factors in biological, psychological, or social areas) that might have a stronger role in determining the diabetes condition.

This research result could be socialized in Health Promotion programs for people with diabetes, to strengthen the emotional situation as positive as possible, and also the level of adherence to medicine. This favorable positive situation might suppress morbidity as well as mortality rates due to diabetes, and the optimal wellbeing of the person achieved.

\section{SUGGESTION}

Empowerment based diabetes selfmanagement support needs to be investigated further to better understand the strengths in controlling diabetes. The power to avoid wrong lifestyle, to manage stress positively, and to be independent in controlling the pressure of this chronic disease, are some self-management perspectives that are suggested for further investigation.

\section{REFERENCES}

1. WHO. Burden: mortality, morbidity, and risk factors; 2013. Available from: http://www.who.int./nmh/publications/ ncd_report_full_en.pdf

2. Badan Penelitian dan Pengembangan Kesehatan. Riset kesehatan dasar 
(RISKESDAS). Laporan Nasional

2013; 1:384. Available from:

http://www.depkes.go.id/resources/do

wnload/general/Hasil\%20Riskesdas\%2

02013.pdf

3. WHO. World health day: diabetes fakta dan angka. Indonesia: WHO

Press; 2016. Available from:

http://www.searo.who.int/indonesia/to

pics/ino-whd-2016-campaign/en/

4. Briggs, H. Problem solving in diabetes self-management: a model of chronic illness self-management behavior. Ann Behav Med 2003; 25(3):182-193.

5. Polonsky, W.H. Diabetes burnout. American Diabetes Association; 1999. Virginia, USA.

6. Pérez, L.E.G., Álvarez, M., Dilla, T., Guillén, V.G., Beltrán, D.O. Adherence to therapies in patients with type 2 diabetes. Diabetes Ther 2013; 4(2):175-194.

7. Rasdianah, N., Martodiharjo, S., Andayani, T.M., Hakim, L. Gambaran kepatuhan pengobatan pasien diabetes melitus tipe 2 di puskesmas daerah istimewa Yogyakarta. Jurnal Farmasi Klinik Indonesia 2016; 5(4):249-257.

8. Martin, A.D. Emotional quality management. Penerbit Arga; 2003. Jakarta, Indonesia.

9. Straub, R.O. Health psychology: a biopsycho-social approach. Worth Publishers, USA; 2014.

10. Infodatin (pusat data dan informasi Kementerian Kesehatan RI). Situasi dan analisis diabetes; 2013. Available from:

http://www.depkes.go.id/resources/do wnload/pusdatin/infodatin/infodatindiabetes.pdf

11. National Diabetic Statistics Report. Estimates of diabetes and its burden in the United States; 2017. Available from:

https://www.cdc.gov/features/diabetesstatistic-report/index.html
12. Charles, E. Predictors of poor glycemic control in type 2 diabetic patients attending public hospitals in Dar es Salaam. Drug, Healthcare, and Patient Safety 2014; 155-165.

13. Juarez, D.T., Sentell, T., Tokumaru, S., Goo, R., Davis, J.W., et al. 2012. Factors associated with poor glycemic control or wide glycemic variability among diabetes patients in Hawaii. Preventing Chronic Disease 2006 2009; 9:1-10.

14. Soelistijo, S.A., Novida, H., Rudijanto, A. Konsensus pengelolaan dan pencegahan diabetes melitus tipe 2 di Indonesia. PB Perkeni; 2015.

15. Penckofer, S., Ferrans, C.E., VelsorFriedrich, B., Savoy, S. Women's dayto-day experiences: the psychological impact of living with diabetes. Diabetes Educ 2007; 4:680-690.

16. Funnell, M.M., Tang, T.S., Anderson, R.M. Developing empowerment-based diabetes self-management support. Diabetes Spectrum 2007; 20(4), 221226.

17. Lam W.Y., Fresco P. Medication adherence measures: an overview. Biomed Res Int 2015; ID 217047. Available from: doi.org/10.1155/2015.

18. Strandberg, R.B., Graue, M., Wentzel, T., Peyrot, M., Thordarson, H.B., Rokne, B. Longitudinal relationship between diabetes specific emotional distress and follow up HbA1c in adults with type I diabetes mellitus. Diabetic Medicine 2015; 32(10): 1304-1310.

19. Perrin, N.E., Davies, M.J., Snoek, F.J., Khunti, K. The prevalence of diabeticspecific emotional distress in people with type 2 diabetes: a systematic review and meta-analysis. Diabet.Med 2017; 34(11): 1508-1520.

20. Aikens, J.E. Prospective associations between emotional distress and poor outcomes in type 2 diabetes. Diabetes Care 2012; 35(12): 2472-2478.

21. Wong, M.C.S., Wu, C.H.M., Wang, H.H.X., Li, H.W., Hui, E.M.T. Association between the 8-item 
Morisky Medication Adherence Scale ( MMAS-8 ), score and glycaemic control among chinese. Jurnal of Clinical Pharmacy 2014; XX (XX): 19. Available from: doi:10.1002/jcph 408.

22. Raum, E., Kra, H.U., Ru, G., Rothenbacher, D., Rosemann, T., Szecsenyi, J., et al. Medication nonadherence and poor glycaemic control in patients with type 2 diabetes mellitus. Diabetic Research and Clinical Practice 2012; 97(12): 377-384.

23. Krapek, K.,King, K., Warren, S.S., George, K.G., Caputo, D.A. Medication adherence and associated HbA1c in type 2 diabetes. Ann Pharmacother 2004; 38(9):1357-62.

24. Berenguera, A., Mollo, A., Mata, C.M. The physical, social, and emotional experiences of people with uncontrolled type 2 diabetes: a qualitative study. Dovepress 2016;10: 2323-2332. Available from: doi https://doi.org/10.2147

25. Ishak, N.H., Yusoff, S.S.M., Rahman, A. Diabetes self-care and its associated factors among elderly diabetes in primary care. Journal of Taibah University Medical Sciences 2017;12(6): 504-511.

26. Coccaro, E.F., Drossos, T., Phillipson, L. HbA1c levels as a function of emotional regulation and emotional intelligence in patients with type 2 diabetes. Prim Care Diabetes 2016; 10(5): 334-41. Available from: doi:10.1016/j.pcd.2016.05.006. 